\title{
The Role of Genital Hiatus (Gh), Perineal Body (Pb), Summation (Gh+Pb) of POP-Q Examination in Maximum Levator Hiatal Area of Women with Symptomatic Pelvic Organ Prolapse
}

\author{
Peran Hiatus Genitalis, Badan Perineum dan Penjumlahannya dari Pemeriksaan Pop-Q \\ pada Luas Area Hiatus Levator Maksimal pada Perempuan dengan Prolaps Organ \\ Panggul Simtomatik
}

\author{
Kukuh W Kustarto, Fernandi Moegni
}

Division of Urogynecology Reconstruction

Departement of Obsterics and Gynecology

Faculty of Medecine Universitas Indonesia

Dr. Cipto Mangunkusumo General Hospital

Jakarta

\begin{abstract}
Objective : To provide data on the correlation of levator hiatus area measurements in symptomatic POP using 3D / 4D Ultrasound with clinical examination of $\mathrm{Gh}, \mathrm{Pb}$ and summation $(\mathrm{Gh}+\mathrm{Pb})$.

Methods : Secondary data analysis of 160 POP patients examined from January 2012 to April 2017 at the Urogynecology Clinic of Dr. Cipto Mangunkusumo Hospital, Jakarta, Indonesia. Patient characteristics, maximum 3D / 4D Ultrasound measurement of Levator Hiatus Area, and clinical measurement results using pelvic organ prolapse quantification system (POP-Q) were recorded.
\end{abstract}

Results : There was a positive correlation between clinical examination and measurement of hiatal area area using ultrasound with $r=0.43$ for Gh length, and the medium correlation on the sum of $\mathrm{Gh}$ and $\mathrm{Pb}$ with $r=0,51$. No correlation for $\mathrm{Pb}$ length with $r=0.23$. The optimal cut to differentiate degrees 2 by 3 is $7.5 \mathrm{~cm} / 29.7 \mathrm{~cm} 2$ and degree 3 by 4 is $8.3 \mathrm{~cm} / 32.1 \mathrm{~cm}^{2}$

Conclusions : Clinical examination by summing the lengths of $\mathrm{Gh}$ and $\mathrm{Pb}$ may be consider reflects the examination of the hiatal area by using transperineal ultrasound to see the strain on levator ani called "ballooning" in an area with limited resources.

Keywords : genital hiatus, levator hiatus area, pelvic organ prolapse, perineal body.

\begin{abstract}
Abstrak
Tujuan : Untuk memberikan data mengenai korelasi pengukuran area hiatus levator pada POP simtomatik mengunakan Ultrasonografi 3D/4D dengan pemeriksaan klinis yaitu panjang $\mathrm{Gh}$, panjang $\mathrm{Pb}$ dan penjumlahannya.
\end{abstract}

Metode : Analisa data sekunder sebanyak 160 pasien POP yang diperiksa dari Januari 2012 hingga April 2017 dipoliklinik Urogynecology Rumah Sakit Dr. Cipto Mangunkusumo (RSCM), Jakarta, Indonesia. Diambil data karakteristik pasien, pengukuran Ultrasonografi 3D/4D maksimal Area Hiatal Levator, dan hasil pengukuran secara klinis dengan menggunakan pelvic organ prolapse quantification system (POP-Q)

Hasil : Terdapat korelasi positif antara pemeriksaan klinis dengan pengukuran luas area hiatal menggunakan USG dengan $r=0,43$ untuk panjang $G h$, dan korelasi pada penjumlahan $\mathrm{Gh}$ dan $\mathrm{Pb}$ dengan $r=0,51$ termasuk kategori sedang, sedangkan untuk panjang $P b$ dengan $r=0,23$ tidak didapatkan adanya korelasi. Didapatkan titik potong optimal untuk membedakan derajat 2 dengan derajat 3 adalah 7,5 $\mathrm{cm} / 29,7 \mathrm{~cm} 2$ dan derajat 3 dan derajat 4 adalah $8,3 \mathrm{~cm} /$ $32,1 \mathrm{~cm}^{2}$

Kesimpulan : Pemeriksaan klinis dengan menjumlahkan panjang $\mathrm{Gh}$ dan panjang $\mathrm{Pb}$ dapat dipertimbangkan untuk mencerminkan pemeriksaan area hiatal dengan mengunakan USG 3 / 4 dimensi transperineal pada daerah dengan sarana terbatas untuk melihat regangan pada levator ani atau yang disebut sebagai "ballooning

Kata kunci : badan perineum, genital hiatus, hiatal levator ani, prolaps organ panggul. 


\section{INTRODUCTION}

Pelvic organ prolapse (POP) is an abnormal descent of pelvic organs such as the uterus, bladder, urethra, and rectum from the normal position into the vagina or out of the vagina due to decreased function of the pelvic organ supporting system. ${ }^{1,2}$ This support function results from interactions between the pelvic bone, muscles, ligaments, fascia and nerves. ${ }^{2}$ POP is part of pelvic floor dysfunction, strongly associated with other pelvic floor disorder symptoms such as urinary incontinence, constipation, decreased sexual quality. ${ }^{3,4}$ The incidence of pelvic organ prolapse in a study was $30.8 \%$ at age above 50 years. An American study found that 79-year-old women had an $11.1 \%$ risk for at least one POP surgery or urinary incontinence, with a possible $29.2 \%$ reoperation. ${ }^{5,6}$ Based on studies in the United States, the operating costs for POP and urinary incontinence reached more than 1 billion dollars. ${ }^{7}$ An increase in financing is also expected to occur, as it is estimated that over the next 30 years the number of women seeking treatment will double, as a result of age and lifestyle changes. ${ }^{8}$

The levator hiatus area is an area formed by the levator ani muscle that is strongly associated with prolapsed occurrence and is a potentially high-potential site or portal for the occurrence of POP and rectal prolapse. ${ }^{9}$ It is also a central opening of the levator plate, which is known to be strongly associated with signs and symptoms of POP and risk for recurrence. There are several explanations that cause excess strain of levator hiatus or so-called ballooning due to congenital or acquired abnormalities. The existence of microtrauma for example over distention, due to hormonal effects on labor and because of the process of childbirth. Subsequent over distence leads to secondary avulsion of the puborectal muscle, where the muscle escapes from its insertion in the symphony bone. Prolapse of the anterior portion of the vagina or cystocele is the most common type of prolapse, and is the most persistent place and the highest incidence of recurrence. ${ }^{10}$

Vaginal delivery is a major risk factor for POP. A study found a mean peak pressure on the baby's head and pelvic floor when straining at $238.2 \pm$ $82.4 \mathrm{~mm} \mathrm{Hg}$. Such pressure is potentially resulting in temporary or permanent strain or injury to maternal tissue. Avulsion levator ani occurs in 15$30 \%$ of women who deliver vaginally Avulsion is a risk factor for 'ballooning' (an abnormal hiatal area at Valsalva maneuver $>25 \mathrm{~cm} 2$ ) and is a risk factor for POP, especially in the anterior and middle compartments., ${ }^{9,11}$

In addition to avulsion, microtrauma or traumatic over distention leads to changes in levator hiatus biometry and boils down to POP.11 Damage to pelvic floor muscle structure during vaginal delivery eliminates the ability to keep the urogenital always closed, so that eventually the ligaments fail to retain the pelvic organs due to persistent intra-abdominal pressure..$^{12}$

In 2005 Dietz HP et al found a significant association between pelvic organ mobility with levator hiatus area at rest and Valsalva maneuvers. ${ }^{13}$ Their further study has suggested that measurement of levator ani distensibility is the most basic approach for determining the biomechanical properties of the muscle, and labor increases the distensibility of the levator ani hiatus, although without significant levator ani trauma. They also found that the levator hiatus area has a very strong statistical relationship with clinical symptoms of POP. Therefore, the distensibility of hiatus may be an independent etiologic factor of POP. ${ }^{9}$ Rodrigues Jr AA et al found that the Levator Ani Subtended Volume (LASV) demonstrated a strong association with the increase in POP levels defined by POP-Q.14 Punarbawa shows a correlation between the maximum of hiatal levator area and the degree of uterine prolapse, the optimal cut off point with the highest sensitivity and specificity was 28.5 $\mathrm{cm} 2 .{ }^{15}$ Santoso showed the optimal cut off point of the levator ani muscle area in distinguishing cystocele grade I-II and III-IV was $29 \mathrm{~cm}^{2}$. The optimal cut of point of the levator ani muscle area in distinguishing rectoceles grade I-II and III-IV was $30 \mathrm{~cm}^{2} .{ }^{16}$ In addition to the ultrasound examination of the above-mentioned hiatal area, there is also a study by Khunda A et al linking the levator hiatal area with clinical examination of the sums of $\mathrm{Gh}$ and $\mathrm{Pb}$ where a $7 \mathrm{~cm}$ cutoff point is defined as an excessive strain of levator hiatus. ${ }^{17}$ Gerges B et al states that the measurements of length of $\mathrm{Gh}$ and $\mathrm{Pb}$ can clinically determine the degree of excess stretching of levator hiatus without the need for ultrasound. ${ }^{18}$ All of these clinical examinations were conducted in 
Caucasian races and have not been studied in the Malay race.

The use of 3 and 4-dimensional ultrasound is ideal for assessing the morphology as well as the dimensions of the pelvic floor. The emergence of ultrasound 3 and 4 dimension provides an advantage in imaging, which can imaging the three areas of the body. This allows both qualitative and quantitative assessment of the pelvic floor support structure, the integrity of the levator ani muscle, the avulsion and in addition to the internal and external sphincters at the same time. Data at the time of examination can be saved and transfer for analysis and interpretation in the future. ${ }^{19}$

The use of Utrasound 3 and 4 dimensions to measure the hiatal levator ani preoperative area is the goal to determine the operating technique to be performed to reduce the genitals of hiatus, whether the use of mesh or the reduction of the genitals hiatus with zakarin levatorplasty. ${ }^{20,21}$ Procurement of ultrasound 3 and 4 dimensions of course requires considerable funds and required special skills to assess the pelvic floor. ${ }^{22}$ Not all hospitals in Indonesia have this facility. Pelvic floor examination with POP-Q is currently a common clinical examination to assess the degree of POP. The measurement sum of the length of the genital hiatus (Gh) and the perineal body $(\mathrm{Pb})$ taken from clinical POP-Q examination can be to determine the degree of hiatal or ballooning strain that equivalent with ultrasound examination. ${ }^{18}$ However, there is a research that shows the suitability of $\mathrm{Gh}$ length with the degree of weight of POP while $\mathrm{Pb}$ does not show a meaningful suitability. ${ }^{23,24}$ Therefore, research needs to be conducted so that methods and techniques of clinical measurement of length of $\mathrm{Gh}$, length of $\mathrm{Pb}$ and addition can be studied in relation to the area of hiatal levator and can be used for clinical benefit and used by many people in the future.

\section{METHOD}

This was a cross-sectional study, where the data source was from secondary data of medical record in POP patient in Urogynecology and reconstruction subdivision department of Obstetrics and Gynecology Dr. Cipto Mangunkusumo Hospital, Jakarta, Indonesia.
Data was taken from January 2012 to April 2017. Inclusion criteria were patients who underwent POP-Q examination, underwent transperineal 3D / 4D ultrasound and summation length of $G h$ and $\mathrm{Pb}$. The POP diagnosis used in this study was a combined diagnosis which used the heaviest degree of the three compartments. Exclusion criteria were patients who could not doing valsava maneuver, pelvic organ malignancy, intra-abdominal tumor and had a history of pelvic surgery. Medical records of patients who have met the inclusion criteria will be taken secondary data of patients covering general patient data, clinical examination data in the form of POP-Q examination that has been done by trainees urogynecology with supervision from consultant urogynecology, and examination data of translabial 3D / 4D ultrasound done by one competent urogynecology consultant using GE Voluson E8 Expert BT09 (GE Medical Systems, Zipf, Austria) with 4.0-9.0 MHz convex volume probe RIC5-9-D (acquisition angle 1200).

All medical records of study subjects who have data of length $\mathrm{Gh}$ and $\mathrm{Pb}$, and hiatal area data, although the other characteristic data are not included in the data analysis process. Numerical data is assessed by Kolmogorov Smirnov's assay for normality and with Coefficient of Variance (COV) calculations for its homogeneity. If the Kolmogorov Smirnov test produces $p>0,05$ or COV $<25 \%$ then the statistical calculation was done with parametric approach and presented as mean. Mean and Standard Deviation, whereas if it did not meet the requirement it is done with nonparametric approach and presented in median mean and ranges. Assessment of the relationship between two numerical variables was done by statistical correlation method based on Spearman test because the distribution was not homogeneous. Relationship with the value of correlation coefficient (R) above 0.3 followed by the determination of the regression formula. $R$ values between 0.3 to 0.5 were included as weak relations categories, between 0.5 to 0.7 as moderate, and above 0.7 include strong relationships. ${ }^{25}$

The determination of the numerical variable intersection value to estimate the degree of POP was done by the Receiver Operating Curve (ROC) method to calculate the amount of Area Under Curve (AUC) as well as the sensitivity, 
specificity, positive predictions, and negative predictions. The limit of statistical significance was used alpha value of 0.05 . This research was proposed to the ethics commission at the Faculty of Medicine, Universitas of Indonesia, so that in the implementation meet the ethical clearance to conduct a research. All patient identities and research results are kept confidential.

\section{RESULT}

In this study, there were 237 initial samples, 77 samples were not performed pelvic floor ultrasound, and among 77 samples there were also prolapse patients already done operation as many as 8 samples. After screening and adjusted for acceptance criteria, 160 samples participated in this study. The results are presented descriptively and analytically.
No pelvic floor ultrasound results $(n=69)$

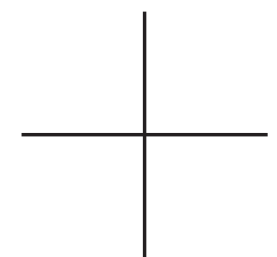

Already performed pelvic organs surgery $(n=8)$

Signed in as a research sample

$$
(n=160)
$$

Diagram 1 : The process of collecting research data

Table 1. Distribution of Subjects According to the Characteristic.

\begin{tabular}{|c|c|c|}
\hline Subject Characteristics & Frequency & $\%$ \\
\hline \multicolumn{3}{|l|}{ Age group $(n=160)$} \\
\hline$<50$ year & 32 & 20.0 \\
\hline $50-59$ year & 56 & 35.0 \\
\hline $60-69$ year & 48 & 30.0 \\
\hline $70+$ year & 24 & 15.0 \\
\hline Mean and SD & $X=57.97$ & $\mathrm{SD}=11.5$ \\
\hline \multicolumn{3}{|c|}{ Body Mass index (BMI) $(n=112)$} \\
\hline Normo $(18-23)$ & 39 & 34.8 \\
\hline Over $(23-27)$ & 46 & 41.1 \\
\hline Obese (> 27) & 27 & 24.1 \\
\hline Mean and SD & $X=25.10$ & $\mathrm{SD}=3.73$ \\
\hline \multicolumn{3}{|l|}{ Parity $(n=145)$} \\
\hline Nulipara & 3 & 2.1 \\
\hline Primipara & 7 & 4.8 \\
\hline Sekundipara & 33 & 22,8 \\
\hline Multipara $(3-5)$ & 83 & 57.2 \\
\hline Grande multipara (> 5) & 19 & 13.1 \\
\hline Median and Range & Med $=3$ & $0-13$ \\
\hline \multicolumn{3}{|l|}{ Delivery method $(n=141)$} \\
\hline Spontaneus & 131 & 92.9 \\
\hline Assisted delivery & 8 & 5.7 \\
\hline C section & 2 & 1.4 \\
\hline Mean and SD & $X=3531$ & $S D=504$ \\
\hline
\end{tabular}




\begin{tabular}{lcc} 
Subject Characteristics & Frequency & \% \\
Menopause status $(\mathbf{n = 1 2 1 )}$ & & \\
Not yet menopause & 29 & 24,0 \\
$1-5$ year & 22 & 18,2 \\
$6-10$ year & 25 & 20,7 \\
$11+$ year & 45 & 37,2 \\
Median and range & Med $=9$ & $0-25$ \\
\hline
\end{tabular}

From table 1, it was observed that not all characteristic variables of the subjects were recorded in the medical record under study. Only the age variable of the subject was fully recorded. Most subjects aged between 50 to 69 years covered $65.6 \%$ with a mean age of 57,97 years and standard deviation was 11,5 year. Nutritional status was only present in 112 subgroups with the overweight group until obese reached $65.2 \%$ with an average body mass index of $25.1+/-3.73$. Data on parity rate reached 145 subjects with multi parity reaching $70.3 \%$ and median averages of 3 deliveries with a maximum of 13 births.

A total of 141 subjects had a record of the last delivery method and $92.9 \%$ were spontaneous labor with an average birth weight of $3351+/-504$ grams. The history of menopause was recorded in 121 medical records with a majority of more than 5 years, which reached $57.9 \%$ with a median of 9 years and the longest reaching 25 years.
Table 2 shows that the degree of uterine prolapse majority in the central compartment at third degrees with $32.5 \%$ and at first degree as a asymptomatic reaches $15 \%$. Based on the cystocele in the anterior compartment, it was also the third degree with $55.0 \%$ and there were normal subjects of $0.6 \%$ and the first degree was $1.9 \%$. Rectocel in the posterior compartment gives normal conditions in 3,1\% subjects and first degree at $7,5 \%$ while the majority was at second degrees with $67,5 \%$.

After the merging of the highest degree of the three compartments, the majority was in the third degree with the number $53.1 \%$. POP Abnormalities of urinary incontinence were recorded in $3.8 \%$ of subjects, while the majority did not experience avulsion which reached $90.6 \%$.

Table2. Distribution of Subjects According to Pelvic Organ Prolapse Conditions

\begin{tabular}{lcc}
\hline Prolapse condition & Frequency & $\%$ \\
\hline Uterine prolapse & 0 & \\
0 Degree & 24 & 0.0 \\
& & 15.0 \\
$1^{\text {st }}$ Degree & 45 & 28.1 \\
$2^{\text {nd }}$ Degree & 52 & 32.5 \\
$3^{\text {rd }}$ Degree & 39 & 24.4 \\
$4^{\text {th }}$ Degree & & \\
Cystocele & 1 & 0.6 \\
0 Degree & 3 & 1.9 \\
$1^{\text {st }}$ Degree & 41 & 25.6 \\
$2^{\text {nd }}$ Degree & 88 & 55.0 \\
$3^{\text {rd }}$ Degree & 27 & 16.9 \\
$4^{\text {th }}$ Degree & & \\
Rectocele & 5 & 3.1 \\
$0^{\text {Degree }}$ & 12 & 7.5 \\
$1^{\text {st }}$ Degree & 108 & 67.5 \\
$2^{\text {nd }}$ Degree & 24 & 15.0 \\
$3^{\text {rd }}$ Degree & 11 & 6.9 \\
$4^{\text {th }}$ Degree & &
\end{tabular}




\begin{tabular}{lcc}
\hline Prolapse condition & Frequency & $\%$ \\
\hline Degrees by merge & & \\
O Degree & 0 & 0.0 \\
1 $^{\text {st }}$ Degree & 0 & 0.0 \\
$2^{\text {nd }}$ Degree & 32 & 20.0 \\
3 $^{\text {rd }}$ Degree & 85 & 53.1 \\
$4^{\text {th } \text { Degree }}$ & 43 & 26.9 \\
Incontinent & & \\
no & 154 & 96.2 \\
yes & 6 & 3. \\
Avulsion m. levator ani & & \\
Negative & 145 & 90.6 \\
Unilateral & 8 & 5.0 \\
Bilateral & 7 & 4.4 \\
\hline
\end{tabular}

\section{Correlation between Clinical Examination and Hiatal Area}

Correlation between uterine prolapse component and hiatal area measured using Spearman methods because the distribution of hiatal area were not homogen. $R$ value of spearman for correlation between $\mathrm{Gh}$ size and hiatal area can be categories as weak correlation with $\mathrm{R}=0.43$. Regression formula may be used to predict hiatal area based on Gh value according to Gh number, however with the weak $\mathrm{R}$ value, there were high error deviation number. And there were no correlation between $\mathrm{Pb}$ value with hiatal area with $R=0.23$, so we cannot make the regression formula from this relationship.

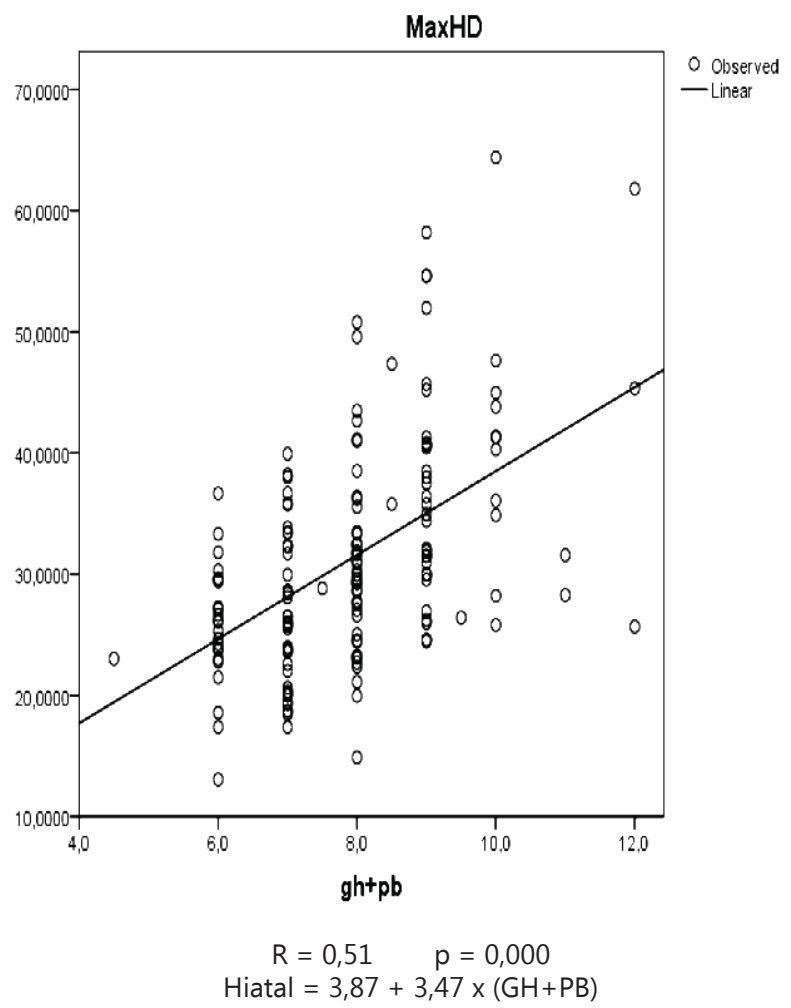

Figure 1. Correlation between addition of $\mathrm{Gh}$ and $\mathrm{Pb}$ with hiatal area $(n=160)$
Figure 1 showed moderate correlation between combination of $\mathrm{Gh}+\mathrm{Pb}$ with hiatal area that may reach $R=0.51$. Regression formula may be used to predict total hiatal area based on the combination of $\mathrm{Gh}+\mathrm{Pb}$ may be used considering the accuracy of the formula that should also be considered.

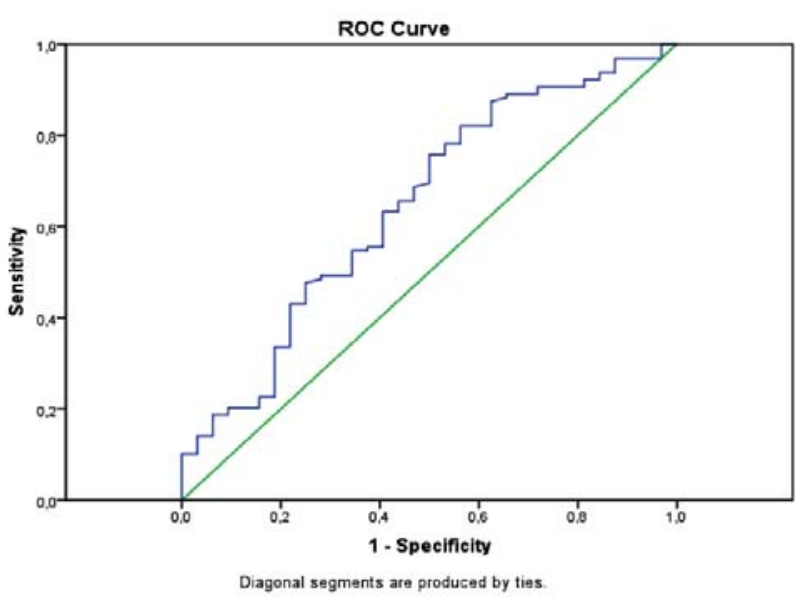

Figure 2. ROC curve from total addition of $\mathrm{Gh}$ and $\mathrm{PB}$ between 2 nddegree and $3 \mathrm{rd} \& 4$ th degree

Area under the curve of this condition was $69.8 \%$ with confidence interval of $95 \%$ between $59.4 \%-80.1 \%$. The cut off point was observed to differentiate between 2 nd degree and $3^{\text {rd }} \&$ $4^{\text {th }}$ degree was $7.25 \mathrm{~cm}$ with sensitivity $64.8 \%$, specificity $68.8 \%$, positive predictive value $89.2 \%$ and negative predictive value $32.8 \%$. 


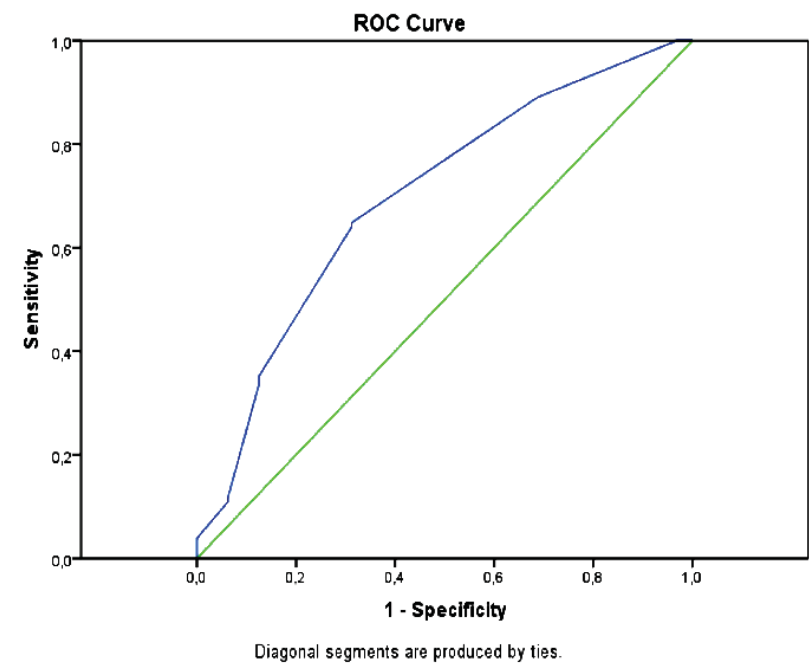

For hiatal area cut off point based on prolapse severity between $2^{\text {nd }}$ degree and $3^{\text {rd }} \& 4^{\text {th }}$ degree, the area under the curve was $64.7 \%$ with confidence interval $95 \%$ between $53.7 \%$ until $75.6 \%$. It was found that the cut off point to differentiate $2^{\text {nd }}$ degree and $3^{\text {rd }}$ or $4^{\text {th }}$ degree were $28.15 \mathrm{~cm}^{2}$ with sensitivity $63.3 \%$, specificity $59.4 \%$, positive predictive value $86.2 \%$ and negative predictive value $28.8 \%$.

Figure 3. ROC curve with total hiatal area between $2^{\text {nd }}$ degree and $3^{\text {rd }} \& 4^{\text {th }}$ degree

Table 3. Cut off Point between $\mathrm{Gh}+\mathrm{Pb}$ and Hiatal Area between Combined Prolapse

\begin{tabular}{|c|c|c|c|c|c|c|}
\hline \multirow[t]{2}{*}{ Prolapse severity } & \multirow[t]{2}{*}{$\mathbf{n}$} & \multirow[t]{2}{*}{ Mean } & \multirow[t]{2}{*}{ SD } & \multicolumn{2}{|c|}{$95 \% \mathrm{CI}$} & \multirow[t]{2}{*}{ Cut of point } \\
\hline & & & & Lower & Upper & \\
\hline $2^{\text {nd }}$ degree & 32 & & & & & \\
\hline $\mathrm{GH}+\mathrm{PB}$ & & 7.14 & 1.23 & 6.75 & 7.53 & \\
\hline Hiatal & & 27.59 & 7.53 & 24.98 & 30.20 & 7.5 \\
\hline $3^{\text {rd }}$ degree & 85 & & & & & 29.7 \\
\hline $\mathrm{GH}+\mathrm{PB}$ & & 7.71 & 1.06 & 7.52 & 7.9 & \\
\hline Hiatal & & 31.21 & 9.49 & 29.19 & 33.23 & 8.3 \\
\hline $4^{\text {th }}$ degree & 43 & & & & & 32.1 \\
\hline $\mathrm{GH}+\mathrm{PB}$ & & 8.74 & 1.49 & 8.35 & 9.1 & \\
\hline Hiatal & & 33.65 & 8.73 & 31.04 & 36.26 & \\
\hline
\end{tabular}

Table 3 demonstrated that the cut off point between $2^{\text {nd }}$ and $3^{\text {rd }}$ degree of prolapse and $3^{\text {rd }}$ and $4^{\text {th }}$ degree of prolapse accordingly based on data distribution and overriding data calculated with $95 \%$ confidence interval. For $\mathrm{Gh}+\mathrm{Pb}$ combined value we can find cut off point of 2 nd and $3^{\text {rd }}$ degree were $7.5 \mathrm{~cm}$. For $3^{\text {rd }}$ and $4^{\text {th }}$ degree were $8.3 \mathrm{~cm}$. For hiatal area, cut off point between2nd and $3^{\text {rd }}$ degree were $29.7 \mathrm{~cm}^{2}$. Between $3^{\text {rd }}$ and $4^{\text {th }}$ degree were $32.1 \mathrm{~cm}^{2}$

\section{DISCUSSION}

POP prevalence were higher in older population until it reach the fifth decade of female life, the prevalence relatively stable from the fifth decade onwards. Wu et al mentioned that 45 years old female may not showed any POP signs / symptoms until she reached 50 or 60 years old..$^{26}$ Tegersted et al, in 2005 did research in Sweden and found that the prevalence of symptomatic POP increased until the age of 60 . In women aged 30-39, 4049 , and $50-59$ found that the prevalence of POP were $4.1,6.2,11.8 \%$. After that, the prevalence of POP remains constant. Between women age 6069 and 70-79 years, the prevalence of POP were $12,2 \%$ and $11 \%$. Using women aged $30-39$ years old as a reference, Odd Ratio POP increased three folds after the age of 50 years old and remain the same in older generations. ${ }^{27}$ The mean age in this research were 57.97 years old (range $26-80$ years old)

Vaginal delivery caused pudenda nerve damage, levator ani muscle damage, and damage of the fascia surrounding the pelvic organ. Traumatic structural damage on the supporting facia and muscle during delivery was the main contributors of urinary incontinence and POP. ${ }^{28}$ Dietz et al showed that spontaneous delivery increased the risk of POP more than three times the baseline level (OR 3.19; 95\%, CI 1.07-9.49), 
Assisted delivery increased the risk of POP more than 5 times of the baseline (OR 5.52; 95\% CI 1.79-17.3) compared to C-Section ${ }^{29}$ Parity may have significant correlation with dimension of hiatal area during Valsalva maneuver and this effect may have influence on the first delivery. ${ }^{30}$ In this research, the mean number of parity are 3 dominated with vaginal delivery $92.9 \%$, assisted delivery $5.75 \%$ and C-section $1.4 \%$.

Santoso BI showed that dysfunction of the pelvic floor caused by biggest baby's weight, Receiver Operating Characteristic (ROC) curve found optimal cut off point of infant weight more than 3325 grams that may cause levator ani muscle trauma. ${ }^{31}$ Different with Boyles, found vaginal delivery with baby weight more than 8 pounds (> 3600 grams) that may have significant relationship with urinary incontinence post partum. ${ }^{32}$ In this research, found that baby's body weight during vaginal delivery was 3,531, 31 gr (range between 2500- 5200 grams)

Obesity was one of the risk factor of emerging signs and symptoms of prolapse, even though it's relationship with objective measurement's not apparent. In SWEPOP research (Swedish Pregnancy, Obesity and Pelvic Floor), symptomatic prolapse organ may increase 3\% with each increase of BMI (Body Mass Index) with OR 1.03; 95\% CI 1.01-1.05..$^{33}$ There are some evidence that obesity is a strong risk factor for incidence and progressivity of urinary incontinence and incontinence alvi. ${ }^{34}$ Chen et al stated that obese women was 4 times more likely to get urinary incontinence and 2 times more likely to get incontinence alvi compared to non-obese women..$^{35}$ From this research, BMI was 2.51 (range 18-39.1) was considered as overweight.

Many researchers made conclusion that menopause was one of the risk factor for POP. A research on 5489 women found that 454 of those with POP signs/symptoms showed an increasing prevalence of POP based on their age, the prevalence will not increase further after 60 years old. ${ }^{36}$ Tegerdst et al found that the prevalence and risk factors of POP increased significantly after 60 years old and the prevalence was stable at those older than 60 years old. ${ }^{26}$ Mothes et al in their research showed that in those that already had had menopause for more than 10 years that menopause is an independent risk factors for prolapse $(p<0.001) .{ }^{27}$ In this research, we found that the average length of menopause are 8.67 years and those that already had menopause $>10$ years in 45 samples (32.7\%).

In combined diagnosis of POP we found that $2^{\text {nd }}$ degree was found in 32 samples $(20 \%), 3^{\text {rd }}$ degree was found in 85 samples $(53.1 \%)$, $4^{\text {th }}$ degree was found in 43 samples (26.9\%), there were no sample with non-prolapse and $1^{\text {st }}$ degree, according to criteria, symptomatic prolapse were those that higher than $2^{\text {nd }}$ degree. ${ }^{28,29}$

Avulsion (macrotrauma) and overdistention traumatic (microtrauma) were the most common etiology of POP. ${ }^{11}$ Majida et al (2012) done research to compare the morphology and function of pelvic floor in 157 POP women with and without the defect of pubovisceral muscle. They found that he prevalence of major pelvic floor muscle defect's around 34\%, similar with other research that showed prevalence between $21-37 \%$. This finding was different with previous opinion by Shek (2009) that stated $15-30 \%$ of female that experienced vaginal delivery had levator ani trauma (avulsion). ${ }^{11}$ In this research, we found that the incidence of avulsion in levator ani muscle's around $9.4 \%$.

Urinary incontinence that's mainly stress incontinence have strong relationship with vaginal delivery. ${ }^{30}$ In female Swedish population aged 20 years old during their first labor, found that vaginal delivery had significant relationship with degree of urinary incontinence severity (OR $1.68,95 \%$ CI 1.40-2.03) and urinary incontinence problem (OR 1.85, 95\% CI 1.42-2.39). ${ }^{30}$ In cohort research in women between 5 years until 10 years after first labor. History of one or more vaginal delivery has significant relationship with odds of stress incontinence (OR 2.9, 95\%, CI 1.5-5.5) but not with overactive bladder (OR 1.7, 95\% CI 0.8-3.5). The effect of vaginal delivery in urinary incontinence mainly happened in postpartum periods. Different compared to the population in this research that's dominated with vaginal delivery in $92.9 \%$ with incidence of urinary incontinence was 3.8\%. This supported Dietz that compared pelvic organ mobility in Caucasians with Asian we found that there's a difference in mobility in anterior compartment and posterior compartment that is smaller, and the central compartment remains the same. ${ }^{31}$ 
The correlation between Gh length and hiatal area showed the correlation coefficient was 0.43 . This show weak but positive relationship between these 2 variables. Lowder et al in 2016 did a research that showed Gh length is a strong predictor of prolapse of apical structure with $\mathrm{Gh}$ length $>3.75 \mathrm{~cm}(\mathrm{ROC}>0.8) .{ }^{32}$ Khunda et al also showed positive correlation between $\mathrm{Gh}$ length and hiatal area with correlation coefficient of $0.52 .{ }^{17}$

Correlation between $\mathrm{Pb}$ length and hiatal area had correlation coefficient 0,24 , this showed no relationship between these 2 variables. This results is the same with previous findings by Dunivan et al in 2015 that showed Pb length does not have any relationship with prolapse degree but $\mathrm{Gh}$ length have relationship with prolapse degree until it reached $3^{\text {rd }}$ degree..$^{33}$

Correlation between the total of $\mathrm{Gh}$ and $\mathrm{Pb}$ length with hiatal area had correlation coefficient of 0.51 showed that there are positive correlation with moderate relationship. ${ }^{25}$ This research results was similar to those written by Khunda et al in the year of 2012 in which the total of Gh and $\mathrm{Pb}$ may have strong relationship with hiatal area $(r=0.722)$. ${ }^{17}$ We found formula to get the total hiatal area from clinical examination of summing $\mathrm{Gh}$ and $\mathrm{Pb}$ length was $3.87+3.47 \times(\mathrm{Gh}+\mathrm{Pb})$, this formula may be used in area without 3D / 4D USG. The sensitivity results of this examination was $64.8 \%$ and indicates that the total of $\mathrm{Gh}$ and $\mathrm{Pb}$ length greater than $7.25 \mathrm{~cm}^{2}$ could show POP $3^{\text {rd }}$ and $4^{\text {th }}$ degree in $64.8 \%$ of cases. Specificity results showed that $68.8 \%$, means that total of $\mathrm{Gh}$ and $\mathrm{Pb}<7.25 \mathrm{~cm}^{2}$ may reveal $2^{\text {nd }}$ degree of POP in $68.8 \%$ of case. The result of positive predictive value of $89.2 \%$ is higher compared than negative predictive value (32.8\%). This result showed that clinical examination result of $\mathrm{Gh}$ and $\mathrm{Pb}$ total $>=7.25 \mathrm{~cm}^{2}$ may predict $3^{\text {rd }}$ and $4^{\text {th }}$ degree POP with high accuracy, clinical examination results of $G h$ and $\mathrm{Pb}$ less than $7.25 \mathrm{~cm}^{2}$ may have low predicting power of $2^{\text {nd }}$ degree of POP, in other words the prevalence of grade 2 POP based on clinical examination may be in reality are undiagnosed $3^{\text {rd }}$ and $4^{\text {th }}$ degree of POP. This may be caused by multifactorial cause of POP, and hiatal levator area (reflexion from pelvic floor muscles)'s not only the main causing factors of POP. Anatomy of pelvic floor supporting muscle's divided into passive and active structure. Passive structure encompassed pelvic bones and supporting tissue such as ligament and endopelvic fascia, active supporting tissue encompasses pelvic floor muscle and the nerves that facilitates tonic contraction and contraction both voluntary and involuntary. Intermittent contraction. Active and passive component of pelvic floor function works as an integrated system that works with each other. ${ }^{34}$ Other factors that may have important repercussions were the damage of supporting tissue (both the collagen and elastin). POP's closely related with a decrease in total collagen and the decrease of collagen solvability, an increase in intermediate intermolecular cross-links and advanced glycation cross links in prolapse tissue. Changes in collagen in prolapse tissue are four times more prevalent, this was clearly shown by matrix metalloproteinase and increased of collagenolytic activity that may in turn cause prolapse of tissue lose collagens. Fibroblast may decrease the collagen production in prolapse tissue; and an increase in the activity of MMP-1, 2 and 9 and a decrease of TIMP-1 activity may cause an increase in collagen turnover. Thus may cause the production of immature new collagen. Most of the researchers found that an increase type III collagen and a decrease of type 1 collagen, thus it may cause a decrease in type I/ type III collagen. ${ }^{35}$

Dietz conducted measurement of hiatal area during Valsalva on 544 women and classified the results to this following findings: mild 25-29.9 $\mathrm{cm}^{2}$, moderate $30-34.9 \mathrm{~cm}^{2}$, marked in 35-39.99 $\mathrm{cm}^{2}$, and severe $\geq 40 \mathrm{~cm} 29$ In a study conducted at Cipto Mangunkusumo Hospital, Jakarta, Indonesia, Punarbawa found that relationship between maximal area of levator hiatal area with degree of uterine prolapse, the optimal cut off point that have the highest sensivity and specificity was $28.5 \mathrm{~cm}^{2} .{ }^{15}$ Santoso showed that optimal cut off point to differentiate it with $1^{\text {st }}-2^{\text {nd }}$ degree and $3^{\text {rd }}-4^{\text {th }}$ degree of cystocele was $29 \mathrm{~cm}^{2}$. Optimal cut off point of hiatal levator ani muscle that differentiate it with $1^{\text {st }}-2^{\text {nd }}$ degree and $3^{\text {rd }}$ $4^{\text {th }}$ degree of rectocele was $30 \mathrm{~cm}^{2} \cdot{ }^{16}$ It is clearly shown that hiatal area that may differentiate $2^{\text {nd }}$ degree and $3^{\text {rd }}-4^{\text {th }}$ degree was smaller in this research.

Research by Gerges et al showed that abnormal hiatal distention which is often called 
as "ballooning" were divided into mild, moderate, marked and severe according to total $\mathrm{Gh}+\mathrm{Pb}$ divided with mean hiatal area which lies between $7.0-7.99 \mathrm{~cm} / 27.3 \mathrm{~cm}^{2}, 8.00-8.9 \mathrm{~cm} / 27.3 \mathrm{~cm}^{2}, 9.0-$ $9.99 \mathrm{~cm} / 35.1 \mathrm{~cm}^{2}$ and $>10 \mathrm{~cm} / 41.9 \mathrm{~cm}^{2}$. This result was different from our findings which showed marked results in $7.5 \mathrm{~cm} / 29.7 \mathrm{~cm}^{2}$ and severe $8.3 /$ $32.1 \mathrm{~cm}^{2}$. We can see in this research that severe degree has more smaller result compare with western research, in accordance with Cheung et al that compared pelvic floor biometry and hip mobility in nullipara Caucasian and Asian women in Hongkong. It was found that Asian has significantly more dense puborectalis muscle, smaller genital hiatus and less mobile pelvic organ compared to Caucasian. ${ }^{30}$ Many research also showed that in different ethnicity, the total hiatal area's also different, and less pelvic organ mobility if compared to Caucasian. Many research also showed that In different ethnicity, total hiatal area may be different from each other. ${ }^{36,37}$

The limitations of this study were primarily cross sectional using secondary data, where sample selection cannot be randomized nor blinding because prolapse degree can be estimated when the patient performed a Valsalva maneuver during pelvic floor transperineal ultrasound examination

\section{CONCLUSION}

Clinical examination by summing $\mathrm{Gh}$ and $\mathrm{Pb}$ length have moderate correlation level $(R=0.51)$ with hiatal area examination using 3D or 4D USG examination that can be used in many health care facilities with limited facility.

\section{RECOMMENDATION}

More research needed to find hiatal area with low severity as a cut off point in asymptomatic and symptomatic patient, to complete data of pelvic organ prolapse in South-East Asian Race especially Indonesian race.

\section{REFERENCES}

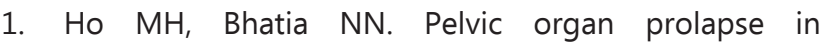
postmenopausal women. In: Lobo RA, editor. Treatment of the postmenopausal woman: basic and clinical aspects. Academic Press; 2007: 739-64.
2. Hendrix SL, Clark A, Nygaard I, Aragaki A, Barnabei V, McTiernan A. Pelvic organ prolapse in the Women's Health Initiative: gravity and gravidity. Am J Obstet Gynecol. 2002;186(6):1160-6.

3. Slieker-ten Hove MCP, Pool-Goudzwaard AL, Eijkemans MJ, Steegers-Theunissen RP, Burger CW, Vierhout ME. The prevalence of pelvic organ prolapse symptoms and signs and their relation with bladder and bowel disorders in a general female population. Int Urogynecol J. 2009;20(9):1037-45.

4. Fritel $X$, Varnoux $N$, Zins $M$, Breart $G$, Ringa $V$. Symptomatic pelvic organ prolapse at midlife, quality of life, and risk factors. Obstet Gynecol. 2009 ;113(3):60916.

5. Clark AL, Gregory T, Smith VJ, Edwards R. Epidemiologic evaluation of reoperation for surgically treated pelvic organ prolapse and urinary incontinence. Am J Obstet Gynecol. 2003;189(5):1261-7.

6. Olsen AL, Smith VJ, Bergstrom JO, Colling JC, Clark $\mathrm{AL}$. Epidemiology of surgically managed pelvic organ prolapse and urinary incontinence. Obstet Gynecol. 1997;89(4):501-6.

7. Subak LL, Waetjen LE, Van Den Eeden $S$, Thom DH, Vittinghoff $E$, Brown JS. Cost of pelvic organ prolapse surgery in the United States. Obstet Gynecol. 2001;98(4):646-51.

8. Chow D, Rodríguez LV. Epidemiology and prevalence of pelvic organ prolapse. Curr Opin Urol. 2013;23(4):293-8.

9. Dietz HP, Shek C, De Leon J, Steensma AB. Ballooning of the levator hiatus. Ultrasound Obstet Gynecol Off J Int Soc Ultrasound Obstet Gynecol. 2008;31(6):676-80.

10. Dietz HP, Franco AVM, Shek KL, Kirby A. Avulsion injury and levator hiatal ballooning: two independent risk factors for prolapse? An observational study. Acta Obstet Gynecol Scand. 2012 ;91(2):211-4.

11. Shek KL, Dietz HP. The effect of childbirth on hiatal dimensions. Obstet Gynecol. 2009;113(6):1272-8.

12. DeLANCEY JO. Anatomy and biomechanics of genital prolapse. Clin Obstet Gynecol. 1993;36(4):897-909.

13. Dietz $H$, Shek $C$, Clarke B. Biometry of the pubovisceral muscle and levator hiatus by three dimensional pelvic floor ultrasound. Ultrasound Obstet Gynecol. 2005;25(6):580-5.

14. Rodrigues AA, Bassaly R, McCullough M, Terwilliger $H L$, Hart S, Downes K, et al. Levator ani subtended volume: a novel parameter to evaluate levator ani muscle laxity in pelvic organ prolapse. Am J Obstet Gynecol. 2012;206(3):244-e1.

15. Punarbawa GM, Moegni F. Hubungan Area Hiatal Levator Dengan Derajat Prolaps Organ Panggul Yang Dinilai Dengan POP-Q. In Jakarta: FKUI-RSCM; 2013.

16. 16. Santoso $H$, Moegni F. Hubungan derajat sistokel dan rektokel dengan area hiatal levator ani. In Jakarta: FKUI-RSCM; 2016.

17. Khunda A, Shek KL, Dietz HP. Can ballooning of the levator hiatus be determined clinically? Am J Obstet Gynecol. 2012 ;206(3):246.e1-4.

18. Gerges B, Kamisan Atan I, Shek KL, Dietz HP. How to determine "ballooning" of the levator hiatus on clinical examination: a retrospective observational study. Int Urogynecol J. 2013;24(11):1933-7. 
19. Barry C, Dietz HP. The use of ultrasound in the evaluation of pelvic organ prolapse. Rev Gynecol Pract. 2005;5(3):182-95.

20. Dietz HP. Pelvic floor ultrasound in prolapse: what's in it for the surgeon? Int Urogynecol J. $2011 ; 22(10)$ :122132.

21. Shek K, Dietz H. Pelvic floor ultrasonography: an update. Minerva Gynecol. 2013;65(1):1-20.

22. Stasi G, Ruoti EM. A critical evaluation in the delivery of the ultrasound practice: the point of view of the radiologist. Int J Med. 2015;9(1):5-10.

23. Digesu GA, Chaliha C, Salvatore S, Hutchings A, Khullar V. The relationship of vaginal prolapse severity tosymptoms and quality of life. BJOG. 2005;112(7):971-6.

24. Dunivan G, Ninivaggio $C$, Lyons $K$, Jeppson $P$, Komesu $Y$, Rogers R. Does Genital Hiatus and Perineal Body Measurements Change with Increasing Prolapse Stage? J Minim Invasive Gynecol. 2015;22(3):S52-3.

25. Mukaka M. A guide to appropriate use of Correlation coefficient in medical research. Malawi Med J J Med Assoc Malawi. 2012;24(3):69-71.

26. Tegerstedt $G$, Maehle-Schmidt $M$, Nyrén $O$, Hammarström M. Prevalence of symptomatic pelvic organ prolapse in a Swedish population. Int Urogynecol J. 2005;16(6):497-503.

27. Mothes A, Radosa M, Altendorf-Hofmann A, Runnebaum I. Risk index for pelvic organ prolapse based on established individual risk factors. Arch Gynecol Obstet. 2016;293(3):617-24.

28. Swift SE, Tate SB, Nicholas J. Correlation of symptoms with degree of pelvic organ support in a general population of women: what is pelvic organ prolapse? Am J Obstet Gynecol. 2003;189(2):372-7.
29. Dietz $\mathrm{H}$, Mann K. What is clinically relevant prolapse? An attempt at defining cutoffs for the clinical assessment of pelvic organ descent. Int Urogynecol J. 2014;25(4):451-5.

30. Gyhagen $M$, Bullarbo $M$, Nielsen $T$, Milsom I. A comparison of the long term consequences of vaginal delivery versus caesarean section on the prevalence, severity and bothersomeness of urinary incontinence subtypes: a national cohort study in primiparous women. BJOG . 2013;120(12):1548-55.

31. Dietz H. Do Asian women have less pelvic organ mobility than Caucasians? Int Urogynecol J. 2003;14(4):250-3.

32. Lowder JL, Oliphant SS, Shepherd JP, Ghetti C, Sutkin G. Genital hiatus size is associated with and predictive of apical vaginal support loss. Am J Obstet Gynecol. 2016;214(6):718-e1.

33. Dunivan $G$, Ninivaggio $C$, Lyons $K$, Jeppson $P$, Komesu Y, Rogers R. Does Genital Hiatus and Perineal Body Measurements Change with Increasing Prolapse Stage? J Minim Invasive Gynecol. 2015;22(3):S52-3.

34. Vergeldt TF, Weemhoff $M$, IntHout J, Kluivers KB. Risk factors for pelvic organ prolapse and its recurrence: a systematic review. Int Urogynecol J. 2015;26(11):155973.

35. Lim VF, Khoo JK, Wong V, Moore KH. Recent studies of genetic dysfunction in pelvic organ prolapse: the role of collagen defects. Aust N Z J Obstet Gynecol. 2014;54(3):198-205.

36. Abdool Z, Dietz HP, Lindeque GB. Are there ethnic differences in the levator hiatus and pelvic organ descent? A Prospective observational study. Ultrasound Obstet Gynecol. 2016;

37. Shek K, Krause H, Wong V, Goh J, Dietz H. Is pelvic organ support different between young nulliparous African and Caucasian women? Ultrasound Obstet Gynecol. 2016;47(6):774-8. 